\title{
Effects of photoperiod modulation and melatonin feeding around drying-off on bovine mammary gland involution
}

\author{
B. Ponchon, ${ }^{*}$ P. Lacasse, $†$ S. Ollier, $†$ and X. Zhao*1 \\ *Department of Animal Science, McGill University, Sainte-Anne-de-Bellevue, Quebec, Canada H9X 3V9 \\ †Sherbrooke Research and Development Centre, Agriculture and Agri-Food Canada, Sherbrooke, Quebec, Canada J1M 0C8
}

\begin{abstract}
The risk for a dairy cow to acquire new intramammary infections is high during the transition from lactation to the dry period, because of udder engorgement and altered immune functions. Once the gland is fully involuted, it becomes much more resistant to intramammary infections. Therefore, strategies to depress milk yield before drying-off and accelerate the involution process after drying-off could be beneficial for udder health. The objective of this study was to assess the effect of photoperiod manipulation and melatonin feeding from $14 \mathrm{~d}$ before to $14 \mathrm{~d}$ after drying-off on the speed of the involution process. Thirty Holstein cows in late lactation were randomly allocated to one of the following treatments: (1) a long-day photoperiod (16 h of light: $8 \mathrm{~h}$ of darkness), (2) a short-day photoperiod (8 h of light: $16 \mathrm{~h}$ of darkness), and (3) a long-day photoperiod supplemented by melatonin feeding $(4 \mathrm{mg} / \mathrm{kg}$ of body weight). Milk and blood samples were collected on $\mathrm{d}-26,-19,-12,-5,-1,1,3,5,7,10$, and 14 relative to the last milking to determine concentrations of mammary gland involution markers and serum prolactin. Additional blood samples were taken around milking on $\mathrm{d}-15$, before the start of the treatments, and on $\mathrm{d}-1$, before drying-off, to evaluate the treatment effects on milking-induced prolactin release. The short-day photoperiod slightly decreased milk production and basal prolactin secretion during the dry period. The milking-induced prolactin surge was smaller on $\mathrm{d}-1$ than on $\mathrm{d}-15$ regardless of the treatments. Lactoferrin concentration, somatic cell count, and BSA concentration as well as matrix metalloproteinase- 2 and -9 activities increased in mammary secretions during the first 2 wk of the dry period, whereas milk citrate concentration and the citrate:lactoferrin molar ratio decreased. The rates of change of these parameters were not significantly affected by the treatments. The long-day photoperiod supplemented by melatonin feed-
\end{abstract}

Received November 7, 2016.

Accepted May 29, 2017.

${ }^{1}$ Corresponding author: xin.zhao@mcgill.ca ing did not affect milk production, prolactin secretion, or mammary gland involution. Under the conditions in this study, photoperiod modulation and melatonin feeding did not appear to affect the rate of mammary gland involution.

Key words: dairy cow, mammary gland involution, photoperiod, prolactin

\section{INTRODUCTION}

After cessation of milking, the bovine mammary gland continues to synthesize milk components during the first days of the dry period, with milk accumulating in the gland. In modern high-producing dairy cows, this accumulation may cause engorgement of the udder, leading to milk leakage and facilitating the entry of microorganisms. The first days of drying-off are therefore critical for dairy cows because of the high susceptibility to acquire new IMI. It has been established that the risk of IMI at calving increases by $77 \%$ for every $5 \mathrm{~kg}$ of milk produced above $12.5 \mathrm{~kg}$ at the time when milking is stopped (Rajala-Schultz et al., 2005). Dingwell et al. (2002) estimated that $16.7 \%$ of quarters that are bacteriologically negative before the cessation of milking become infected during the dry period regardless of antibiotic treatments. The beginning of a dry period is also the time of starting active involution in mammary glands. Active involution is a remodeling process that takes place at the end of a lactation period after cessation of milking or suckling in female mammals and through which the gland returns to a nonlactating state. In cows, this process starts as soon as $2 \mathrm{~d}$ after the last milk removal (Holst et al., 1987) and seems to be complete after approximately 21 d (Hurley, 1989; Akers et al., 1990). When the involution process is advanced, mammary glands become much more resistant to new IMI (Oliver and Smith, 1982). Consequently, a strategy that speeds up the involution process would be a valuable tool to improve mammary gland resistance and udder health around drying-off.

Prolactin plays a survival role during mammary gland involution by inhibiting the increase in metalloproteinase (MMP) expression and preventing mammary 
epithelial cell apoptosis (Accorsi et al., 2002; Flint et al., 2006). In rats, a deficiency in prolactin induced the involution process (Travers et al., 1996). Furthermore, there is compelling new evidence that prolactin plays a galactopoietic role during bovine lactation (Lacasse et al., 2011, 2012). Therefore, the inhibition of the prolactin signal around drying-off may help to decrease milk production before the start of a dry period and to hasten mammary gland involution by removing the inhibition exerted by prolactin. It has been shown that the inhibition of prolactin secretion by a dopaminergic agonist, quinagolide, successfully decreased milk production in cows (Lacasse et al., 2011) and hastened bovine mammary gland involution (Ollier et al., 2013). In addition, milk yield before drying-off influences the involution process and can affect natural defense systems during the dry period (Silanikove et al., 2013).

Modulating the photoperiod, which is the relative duration of light and dark exposure within a day, affects both prolactin secretion and milk production. Ewes (Morrissey et al., 2008), goats (Garcia-Hernandez et al., 2007), and cows (Peters et al., 1981) exposed to a long day photoperiod (LDPP; more than $16 \mathrm{~h}$ of light/d) during lactation produce more milk than those exposed to a short day photoperiod (SDPP; less than $12 \mathrm{~h}$ of light/d). When the photoperiod is modulated during a dry period, the effects on milk production during the subsequent lactation are different. Cows exposed to SDPP during the dry period produce more milk during the following lactation than cows exposed to LDPP (Miller et al., 2000; Auchtung et al., 2005; Lacasse et al., 2014). During either lactation or the dry period, LDPP stimulated prolactin secretion, whereas SDPP reduced it (Dahl et al., 1997; Miller et al., 2000; Auchtung et al., 2005). Moreover, treatment with melatonin, which is a hormone synthesized during darkness by the pineal gland, induced a reduction in both milk yield and circulating prolactin concentrations (Auldist et al., 2007). Therefore, exposing cows to SDPP during late lactation or treating them with melatonin during late lactation could decrease milk production before drying-off and reduce the prolactin signal, thus facilitating mammary gland involution.

The objective of this study was to evaluate the effect of photoperiod manipulation and melatonin feeding on the speed of the involution process. Different involution markers, such as SCC, lactoferrin, BSA, and citrate concentrations in milk and mammary secretions, as well as matrix metalloproteinase-2 (MMP-2) and -9 (MMP-9) activities, were determined to assess the extent of the involution process. In particular, our primary focus was on investigating the changes of lactoferrin, BSA, prolactin, and citrate concentrations among the treatments.

\section{MATERIALS AND METHODS}

\section{Animals and Experimental Design}

The experiment was conducted in accordance with the guidelines of the Canadian Council on Animal Care (CCAC, 1993) and approved by the Animal Ethics Committee of McGill University. A total of 30 first- to third-parity Holstein dairy cows in late lactation (327 \pm 10 DIM at the start of the treatments) were used in this experiment. The cows were randomly assigned to 1 of 3 groups of 10 animals according to their milk production, parity, and SCC. Before the treatments, the cows were exposed to LDPP $[16 \mathrm{~h}$ of light (from natural light and artificial light): 8 h of darkness]. Each group received 1 of the following treatments: (1) LDPP, (2) SDPP (12 h of darkness/1 h of light/4 h of darkness $/ 7 \mathrm{~h}$ of light), and (3) LDPP supplemented with melatonin feeding (LDPP+MEL; $4 \mathrm{mg} / 100 \mathrm{~kg}$ of $\mathrm{BW}$ ). The melatonin dosage was chosen based on previous studies (Sanchez-Barcelo et al., 1991; Lacasse et al., 2014). In the SDPP group, $1 \mathrm{~h}$ of light had been inserted during the $16 \mathrm{~h}$ of darkness schedule to allow morning milking, observing the animals and cleaning the stalls. The cows exposed to SDPP were housed in a room separated from the rest of the herd. The lights in that room were controlled by an automatic timer and were on from 0700 to $0800 \mathrm{~h}$ and from 1200 to $1900 \mathrm{~h}$. Each treatment started $14 \mathrm{~d}$ before drying-off and lasted $14 \mathrm{~d}$ after drying-off, for a total duration of 28 d. Melatonin (Sigma-Aldrich Canada Co., Oakville, $\mathrm{ON})$ was dissolved in sterile distilled water $(1 \mathrm{~g} / \mathrm{L})$, and a sufficient volume of the melatonin solution to reach a concentration of $4 \mathrm{mg} / 100 \mathrm{~kg}$ of BW was mixed into the diet of the LDPP+MEL cows $1 \mathrm{~h}$ after the morning milking.

The cows were milked twice daily at around 0700 and $1800 \mathrm{~h}$, and milk yield was recorded during the last 4 wk before drying off. The cows exposed to SDPP were moved to the regular barn for milking only. However, to avoid IMI and to maintain health of the cows engaged in the experiment, an extra milking was performed on d 2 to 3 of the dry period to release udder pressure and to reduce mammary gland engorgement. The cows were fed ad libitum a late-lactation diet containing (on a DM basis) $59.0 \%$ corn silage, $3.1 \%$ dry hay, $26.5 \%$ corn grain, $6.0 \%$ soybean meal, $3.1 \%$ nonmineral supplement, and 2.3\% mineral supplement. After drying-off, the cows were fed only dry hay until d 14 .

\section{Sample Collection}

Milk samples $(50 \mathrm{~mL})$ were manually collected before drying-off on $\mathrm{d}-26$ and -19 (before treatment) and 
$\mathrm{d}-12,-5$, and -1 (after the start of treatments) from the 4 quarters before the morning milking. Mammary secretion samples (between 25 and $50 \mathrm{~mL}$ depending on the volume of harvestable milk) were also collected in the same way on d $1,3,5,7,10$, and 14 after dryingoff. After collection, the milk and mammary secretion samples from the quarters were centrifuged $(1,900 \times g$, $4^{\circ} \mathrm{C}, 15 \mathrm{~min}$ ), defatted, and stored at $-20^{\circ} \mathrm{C}$ until determination of lactoferrin, citrate, and BSA concentrations and MMP-2 and MMP-9 activities. After the last mammary secretion sampling, on d 14, the cows were infused with antibiotics (Novodry Plus, Zoetis Canada Inc., Kirkland, QC, Canada) and an internal teat sealant (OrbeSeal, Zoetis Canada Inc.).

On the same days as the milk and mammary secretion samples were collected, caudal blood samples $(10 \mathrm{~mL})$ were taken $30 \mathrm{~min}$ before the morning milking. The blood samples were left at room temperature for $2 \mathrm{~h}$ before being centrifuged $\left(1,900 \times g, 4^{\circ} \mathrm{C}, 15 \mathrm{~min}\right)$. Serum was harvested and stored at $-20^{\circ} \mathrm{C}$ until determination of prolactin concentration.

On $\mathrm{d}-15$, just before the beginning of the treatments, and on $\mathrm{d}-1$, just before drying-off, a series of blood samples were collected before, during, and after the evening milking $(-30,-20,-10,0,3,5,7,10$, $15,20,25,30,40$, and $60 \mathrm{~min}$ relative to the start of milking) through a catheter (Angiocath intravenous catheter, BD, Mississauga, ON, Canada) inserted into a jugular vein. After collection, the serum samples were prepared as described above and stored at $-20^{\circ} \mathrm{C}$ until determination of prolactin concentration.

\section{Sample Analyses}

Somatic cell counts were measured using an automatic cell counter (DeLaval International AB, Tumba, Sweden), following the manufacturer's instructions. After drying-off, the mammary secretion samples were diluted with commercial microfiltered skim milk until the SCC reached a value between 100 and 200 cells $/ \mu \mathrm{L}$.

Concentrations of BSA, lactoferrin, and citrate in milk and mammary secretions were measured as previously described (Ponchon et al., 2014). Before each analysis, milk and mammary secretion samples $(2 \mathrm{~mL})$ were centrifuged $\left(1,900 \times g, 4^{\circ} \mathrm{C}, 15 \mathrm{~min}\right)$. The concentration of BSA in milk and mammary secretions was analyzed by a colorimetric assay. The intra- and interassay coefficients of variation were 3.82 and $7.74 \%$, respectively. The concentration of lactoferrin in milk and mammary secretions was measured by ELISA using a commercial bovine lactoferrin ELISA quantitation set (Bethyl Laboratories Inc., Montgomery, TX). The intra- and interassay coefficients of variation were 2.08 and $8.95 \%$, respectively. The concentration of ci- trate in milk and mammary secretions was measured by an enzymatic assay using a commercial citrate assay kit (Megaenzyme International Ireland, Bray, Ireland). The intra- and interassay coefficients of variation were 1.87 and $6.46 \%$, respectively.

As an indicator of the progress of involution, the citrate:lactoferrin molar ratio was calculated for each sample by dividing the molar concentration of citrate [citrate concentration/citrate molecular weight $(192.1 \mathrm{~g} / \mathrm{mol})]$ by the molar concentration of lactoferrin [lactoferrin concentration/lactoferrin molecular weight $(78,056 \mathrm{~g} / \mathrm{mol})]$. Gelatinase (MMP-2 and MMP-9) activities in milk and mammary secretions were analyzed by gelatin zymography as previously described by Ponchon et al. (2014). The activities of these 2 gelatinases in milk and mammary secretions were analyzed by performing gelatin zymography.

The concentration of prolactin in serum was determined by a RIA as described by Bernier-Dodier et al. (2011). Bovine prolactin, rabbit antiserum specific for bovine prolactin, and goat anti-rabbit gamma globulin were from the National Hormone and Peptide Program (Harbor-UCLA Medical Center, Torrance, CA). The intra- and interassay coefficients of variation were 4.20 and $9.47 \%$, respectively.

\section{Statistical Analysis}

Data were analyzed separately for the pretreatment period $(\mathrm{d}-26$ and -19$)$, the pre-drying-off treatment period $(\mathrm{d}-12,-5$, and -1$)$, and the post-drying-off treatment period (from d 1 to 14) by ANOVA using the MIXED procedure of the SAS package (version 9.0, SAS Institute Inc., Cary, NC). Time was used as a repeated effect, and cow (treatment) was used as the subject. The following model was used in the ANOVA:

$$
\mathrm{Y}_{\mathrm{ijk}}=\mu+\operatorname{trt}_{\mathrm{i}}+\mathrm{cow}_{\mathrm{j}}+\text { day }_{\mathrm{k}}+\left(\operatorname{trt}_{\mathrm{i}} \times \text { day }_{\mathrm{k}}\right)+\mathrm{e}_{\mathrm{ijk}},
$$

where $Y_{\mathrm{ijk}}$ is the measured value of the dependent variable of the jth cow on the ith treatment on the kth day, $\mu$ is the overall mean of the dependent variable, $\operatorname{trt}_{\mathrm{i}}$ is the fixed effect of the ith treatment on the dependent

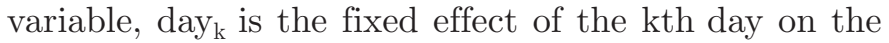
dependent variable, $\operatorname{trt}_{\mathrm{i}} \times$ day $_{\mathrm{k}}$ is the fixed effect of the interaction of $\operatorname{trt}_{\mathrm{i}}$ and $\mathrm{day}_{\mathrm{k}}$ on the dependent variable, and $e_{i j k}$ is the random residual effect associated with the jth cow on the ith treatment on the kth day.

The amount of prolactin released during milking was calculated by determining the area under the curve between 0 and 40 min relative to the start of milking. Volumes of milk measured during the pretreatment period between $\mathrm{d}-26$ and -15 were averaged and used as a covariate for milk production data analysis between 
$\mathrm{d}-14$ and -1 . All data except milk production and prolactin concentration were $\log _{10}$-transformed before analysis. Orthogonal contrasts were used to compare least squares means between the SDPP group and the LDPP and LDPP+MEL groups, and between the LDPP and the LDPP+MEL groups. The least squares means of the SDPP and LDPP+MEL groups were compared by using the Tukey-Kramer adjustment. Differences were considered statistically significant at $P \leq$ 0.05. During the experiment, 2 cows (1 from the SDPP group and 1 from the LDPP+MEL group) displayed clinical signs of mastitis in 3 quarters after drying-off, and those cows' values of involution markers were removed from the statistical analysis.

\section{RESULTS}

\section{Prolactin Concentration}

Before the start of the treatments, even though basal serum prolactin concentrations in SDPP cows tended to be greater than those of the other 2 groups, we did not observe any significant difference in the basal serum prolactin concentrations among the 3 groups of cows (Figure 1A). Before drying-off, we observed a treatment $\times$ day interaction $(P=0.001)$, with a faster decline in prolactin concentrations in the SDPP-exposed cows. After drying-off, the basal serum prolactin concentration declined $(P \leq 0.05)$ and was lower in the SDPP group than in the other 2 groups $(P=0.03)$. The basal serum prolactin concentration in LDPP + MEL cows was not significantly different from that of LDPP cows.

Before the start of the treatments, milking-induced prolactin release was not different among the 3 groups of cows on d -15 (Figure 1B). The day before dryingoff, basal prolactin concentration and the amount (area under the curve) of prolactin released at milking tended to be lower in the cows exposed to SDPP than in the cows in the other 2 groups $(P=0.1$ and $P=0.07$, respectively; Figure 1C). Regardless of treatment, basal prolactin concentrations and the amount of prolactin released at milking were lower on $\mathrm{d}-1$ than on $\mathrm{d}-15$ $(P=0.01$ and $P=0.001$, respectively).

\section{Milk Production}

Before the start of the treatments ( $\mathrm{d}-26$ and -19$)$, milk production was similar in the 3 groups of animals, averaging $23.8,23.3$, and $24.0 \pm 1.7 \mathrm{~kg} / \mathrm{d}$ for the SDPP, LDPP, and LDPP+MEL groups, respectively. After the treatments began, milk production declined progressively until the cessation of milking in all 3 groups $(P$ $\leq 0.001$; Figure 2$)$ and was lower in the SDPP cows $(P$ $\leq 0.01)$ than in the LDPP and LDPP+MEL cows. No significant difference in milk production was observed between LDPP and LDPP +MEL cows from $d-14$ and -1 .

\section{Mammary Gland Involution Markers}

Before the start of the treatments, SCC, the concentrations of lactoferrin, citrate, and BSA, the citrate: lactoferrin molar ratio, and MMP-2 and MMP-9 activities in milk were not different among the 3 groups of animals.

From the beginning of the treatments until dryingoff, BSA concentrations (Figure 3A), SCC (Figure 3B), citrate concentrations (Figure 4A), and lactoferrin concentrations (Figure 4B) in milk did not differ among the treatments. The citrate:lactoferrin ratio (Figure $4 \mathrm{C})$ was also unaffected by the treatments. Milk MMP2 and MMP-9 activities (Figure 5) increased during this period $(P \leq 0.001$ and $P \leq 0.05$, respectively) but were not affected by the treatments.

After drying-off, BSA concentration (Figure 3A), SCC (Figure 3B), and lactoferrin concentration (Figure $4 \mathrm{~B})$ in mammary secretions increased $(P \leq 0.001)$. However, none of them were affected by the treatments. Similarly, the citrate:lactoferrin molar ratio declined after drying-off $(P \leq 0.001)$ but was not affected by treatments. The activities of MMP-2 and MMP-9 increased $(P \leq 0.001)$ during involution (Figure 5$)$. The activity of MMP-9 tended to be greater $(P=0.07)$ in the SDPP cows than in the LDPP and LDPP+MEL cows. The activity of MMP-2 was not affected by the treatments.

\section{DISCUSSION}

Basal prolactin concentrations declined faster before drying-off and were lower after drying-off in blood of the cows exposed to SDPP than in blood of the LDPP and LDPP+MEL cows. In addition, these cows tended to have less prolactin released during milking than the cows exposed to LDPP and LDPP+MEL did. The effects of SDPP on prolactin secretion in this study are in accordance with previous studies (Dahl et al., 1997; Miller et al., 2000; Lacasse et al., 2014). Nevertheless, the effect before drying-off was lower than expected because the SDPP cows tended to have greater prolactin concentrations before the start of the treatments. Moreover, cows were in late lactation, a period when prolactin release naturally decreases (Miller et al., 2006), whereas previous works were performed either on early- or mid-lactation cows. The relatively short exposure to the treatments before drying-off may also have contributed to the small differences noted before drying-off. 


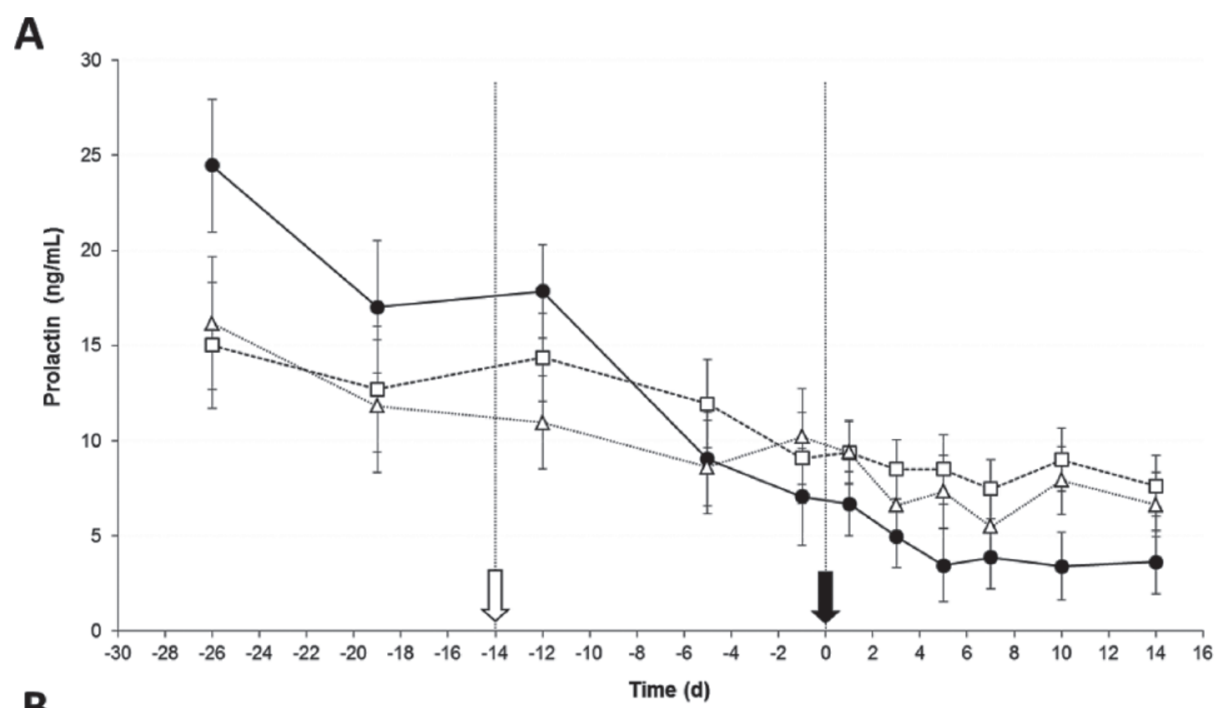

B
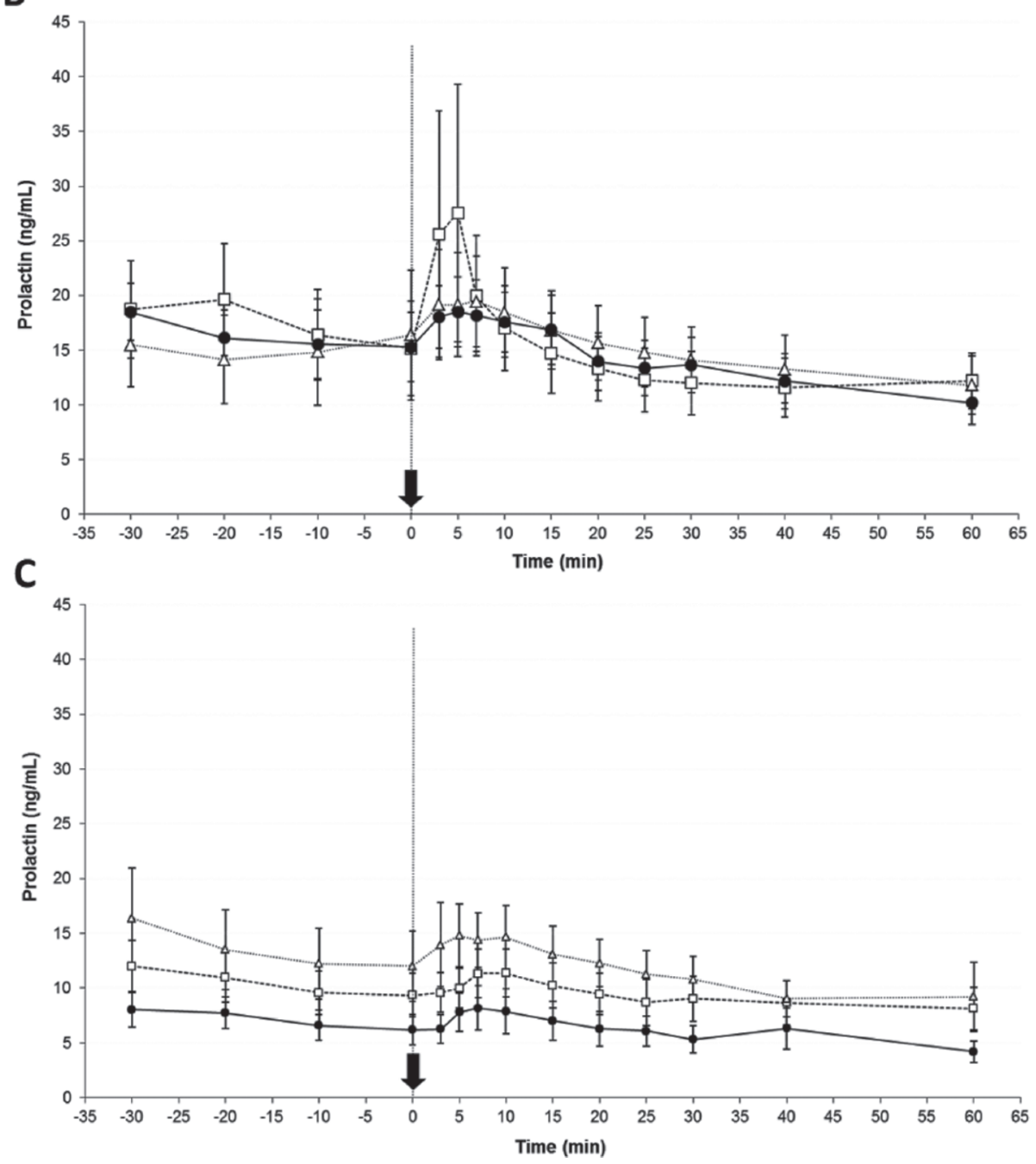

Figure 1. Basal blood prolactin concentrations (A), concentrations of prolactin released during the evening milking on d -15 (B), and concentrations of prolactin released during the evening milking on $\mathrm{d}-1(\mathrm{C})$ in cows exposed to a short-day photoperiod $(\mathbf{\mathrm { c }} ; \mathrm{n}=9$ for $\mathrm{A}$ and $\mathrm{n}=10$ for $\mathrm{B}$ and $\mathrm{C})$, to a long-day photoperiod $(\square ; \mathrm{n}=10)$, or to long-day photoperiod plus oral administration of melatonin $(\Delta ; \mathrm{n}=9$ for $\mathrm{A}$ and $\mathrm{n}=$ 10 for B and C) from $14 \mathrm{~d}$ before to $14 \mathrm{~d}$ after drying-off. In panel A, the white arrow indicates the beginning of the treatments, and the black arrow indicates the start of drying-off. In panels B and C, the black arrow indicates the start of milking. Data are presented as LSM \pm SEM. 
Exposing cows to SDPP accelerated the decline of milk production before drying-off. The effects of photoperiod on milk production in dairy cows are well known (for review, see Dahl and Petitclerc, 2003; Dahl, 2008). The parallel decline between prolactin concentration and milk production suggests that prolactin is the main driver of the effect of photoperiod on milk production. Auldist et al. (2007) reported that melatonin administered as slow-release s.c. implants for 12 wk reduced plasma prolactin concentrations by $4 \mathrm{wk}$ of treatment and decreased milk production by $6 \mathrm{wk}$ of treatment. Considering that SDPP decreased basal prolactin concentrations faster before drying-off and after dryingoff and tended to decrease milking-induced prolactin release, it appears that prolactin played a pivotal role in the effect of photoperiod on milk production.

In the present study, feeding melatonin $14 \mathrm{~d}$ before and $14 \mathrm{~d}$ after drying-off did not affect blood prolactin concentrations and milk production. A few previous studies reported that feeding melatonin was able to decrease blood prolactin levels in cattle. For instance, feeding melatonin $(4 \mathrm{mg} / \mathrm{kg}$ of BW) in the middle of a long day (16 h of light:8 $\mathrm{h}$ of darkness) reduced prolactin concentrations and mammary parenchymal growth in prepubertal heifers (Sanchez-Barcelo et al., 1991). In late-lactation cows, feeding melatonin for $8 \mathrm{wk}$ was able to suppress prolactin secretion (Dahl et al., 2000). Again, the relative short treatment duration may have contributed to the absence of effect of melatonin on prolactin secretion in the present study. However, compared with the SDPP, effects of melatonin administration are less pronounced and are not necessarily associated with a decrease in milk production. For example, administration of 12 implants of melatonin $(18 \mathrm{mg} /$ implant) to dairy cows at drying-off moderately suppressed prepartum prolactin concentrations but did not affect milk production postpartum (Garcia-Ispierto et al., 2013). In addition, melatonin feeding did not affect milk yield in late lactation cows (Dahl et al., 2000). In prepartum cows and heifers, prolactin concentration was reduced by melatonin feeding, but not as much as by the SDPP (Lacasse et al., 2014). The results of the present experiment do not support the hypothesis that feeding melatonin can mimic SDPP in cattle.

After the cessation of milking, milk composition changes dramatically because of a decrease in the synthesis and the secretion of milk components by mammary epithelial cells and an increase in tight junction

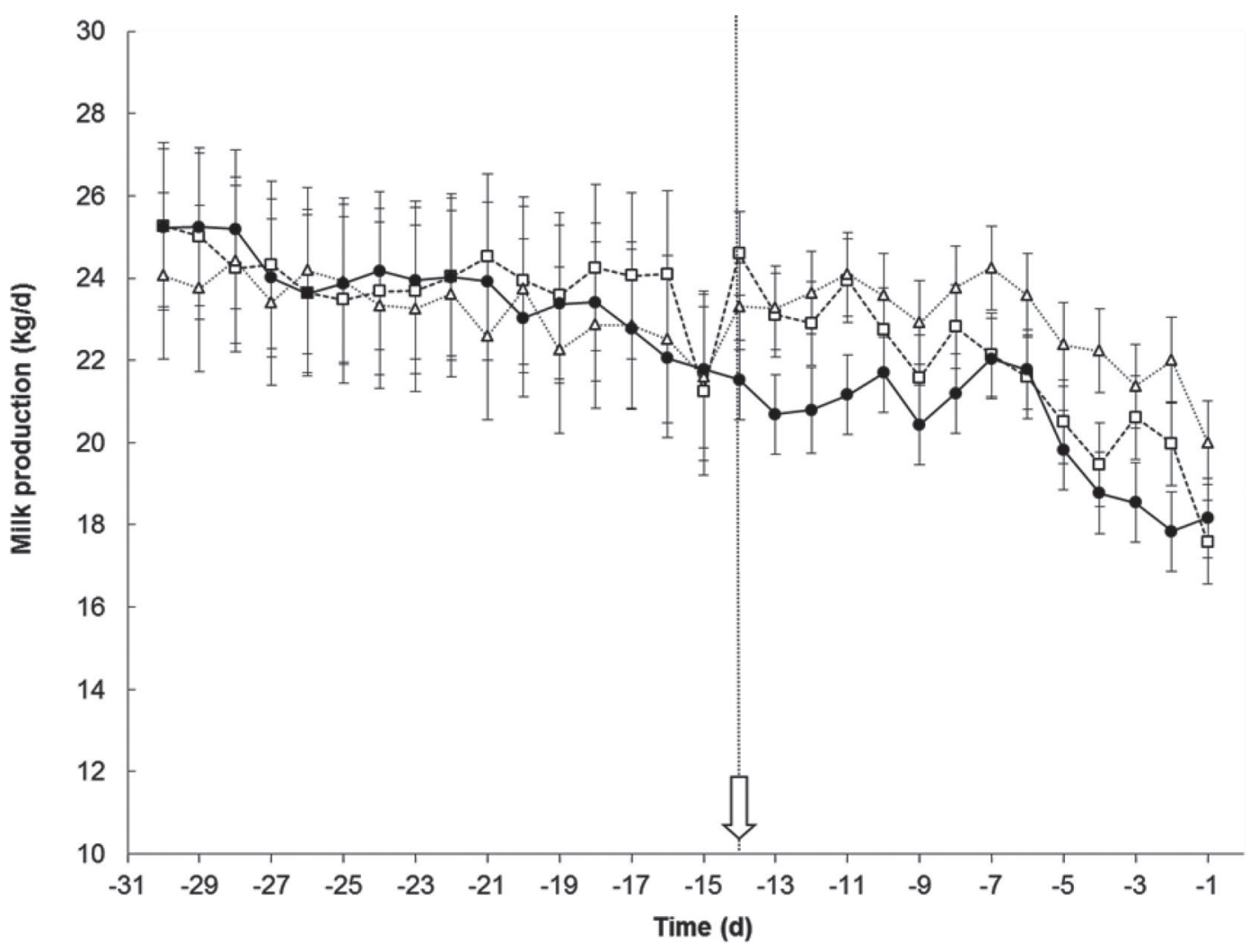

Figure 2. Milk production during the last month of lactation from cows exposed to a short-day photoperiod $(\mathbf{\bullet}$; $\mathrm{n}=10)$, to a long-day photoperiod $(\square ; \mathrm{n}=10)$, or to a long-day photoperiod and treated with oral administration of melatonin $(\Delta ; \mathrm{n}=10)$ from $14 \mathrm{~d}$ before to $14 \mathrm{~d}$ after drying-off. The white arrow indicates the beginning of the treatments. Data are presented as LSM \pm SEM. 
A

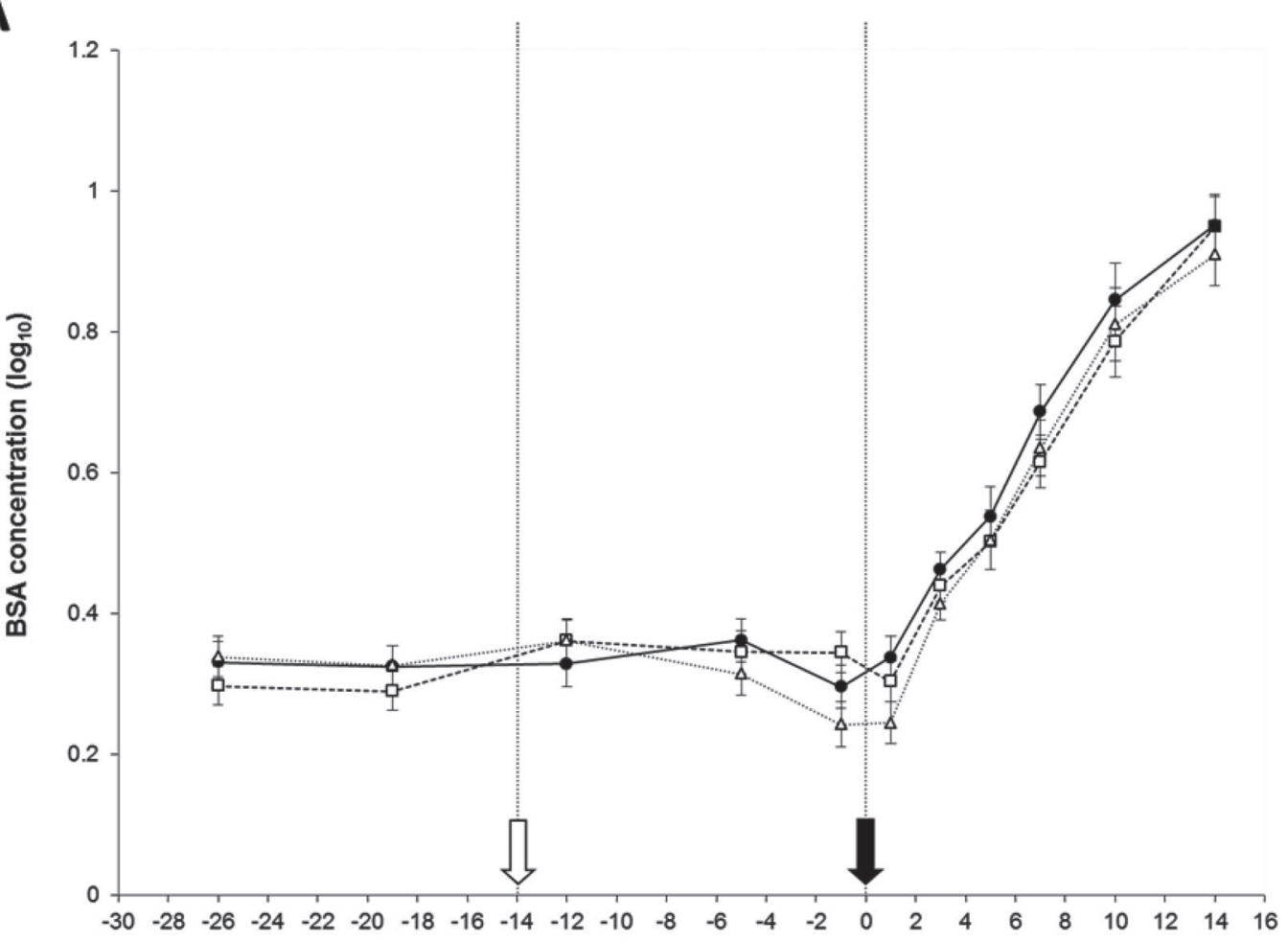

B

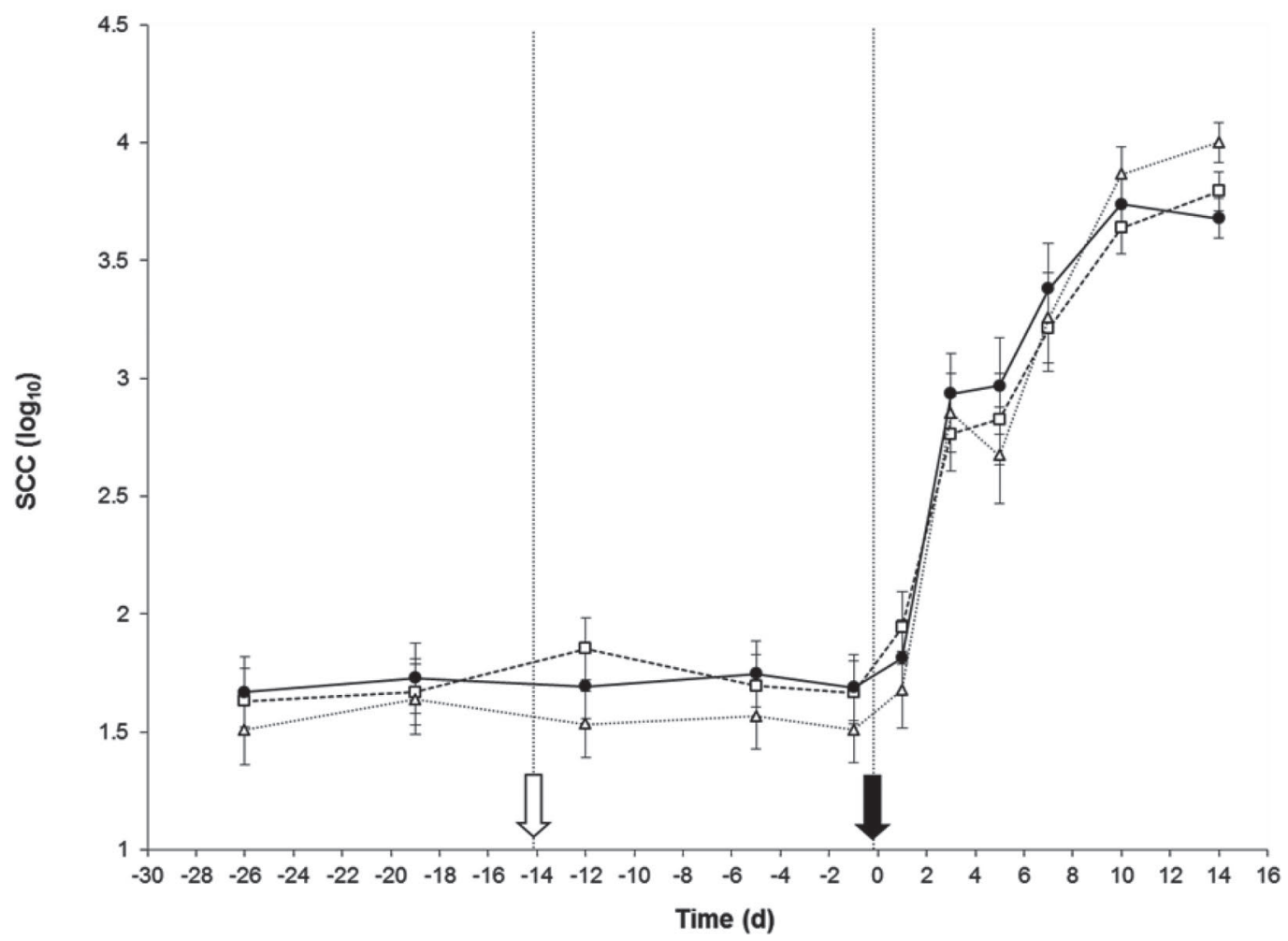

Figure 3. Concentration of BSA (A) and SCC (B) in milk and mammary secretions from cows exposed to a short-day photoperiod $(\bullet ; n=$ 9), to a long-day photoperiod $(\square ; \mathrm{n}=10)$, or to a long-day photoperiod and treated with oral administration of melatonin $(\Delta ; \mathrm{n}=9)$ from $14 \mathrm{~d}$ before to $14 \mathrm{~d}$ after drying-off. The white arrow indicates the beginning of the treatments, and the black arrow indicates the start of drying-off. Data are presented as LSM \pm SEM of $\log _{10}$-transformed values. 
A

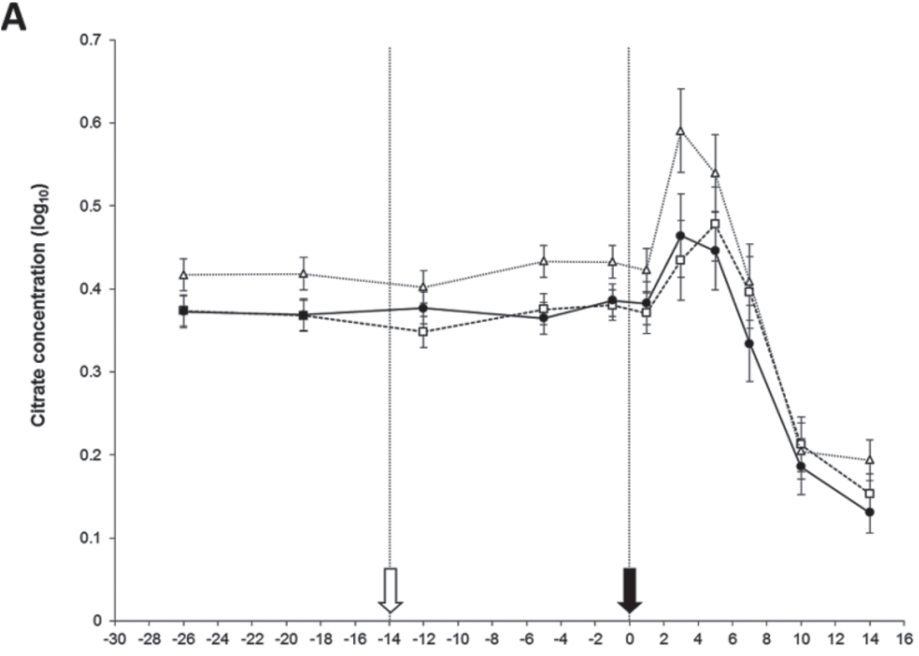

B
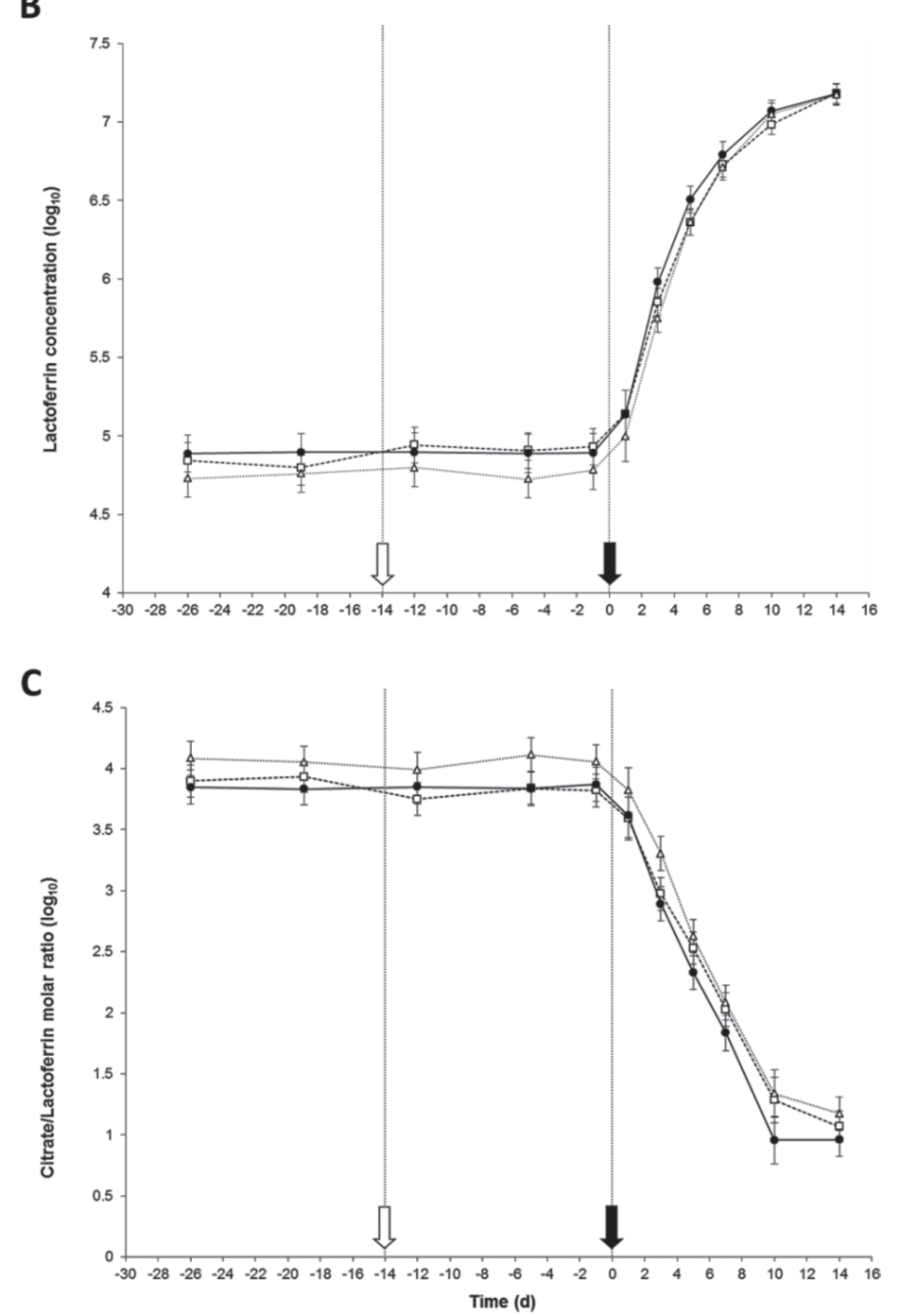

Figure 4. Citrate concentration (A), lactoferrin concentration (B), and citrate:lactoferrin ratio (C) in milk and mammary secretions from cows exposed to a short-day photoperiod $(\mathbf{\bullet} ;=9)$, to a long-day photoperiod $(\square ; \mathrm{n}=10)$, or to a long-day photoperiod and treated with oral administration of melatonin $(\Delta ; \mathrm{n}=9)$ from $14 \mathrm{~d}$ before to $14 \mathrm{~d}$ after drying-off. The white arrow indicates the beginning of the treatments, and the black arrow indicates the start of drying-off. Data are presented as LSM \pm SEM of $\log _{10}$-transformed values. 
A

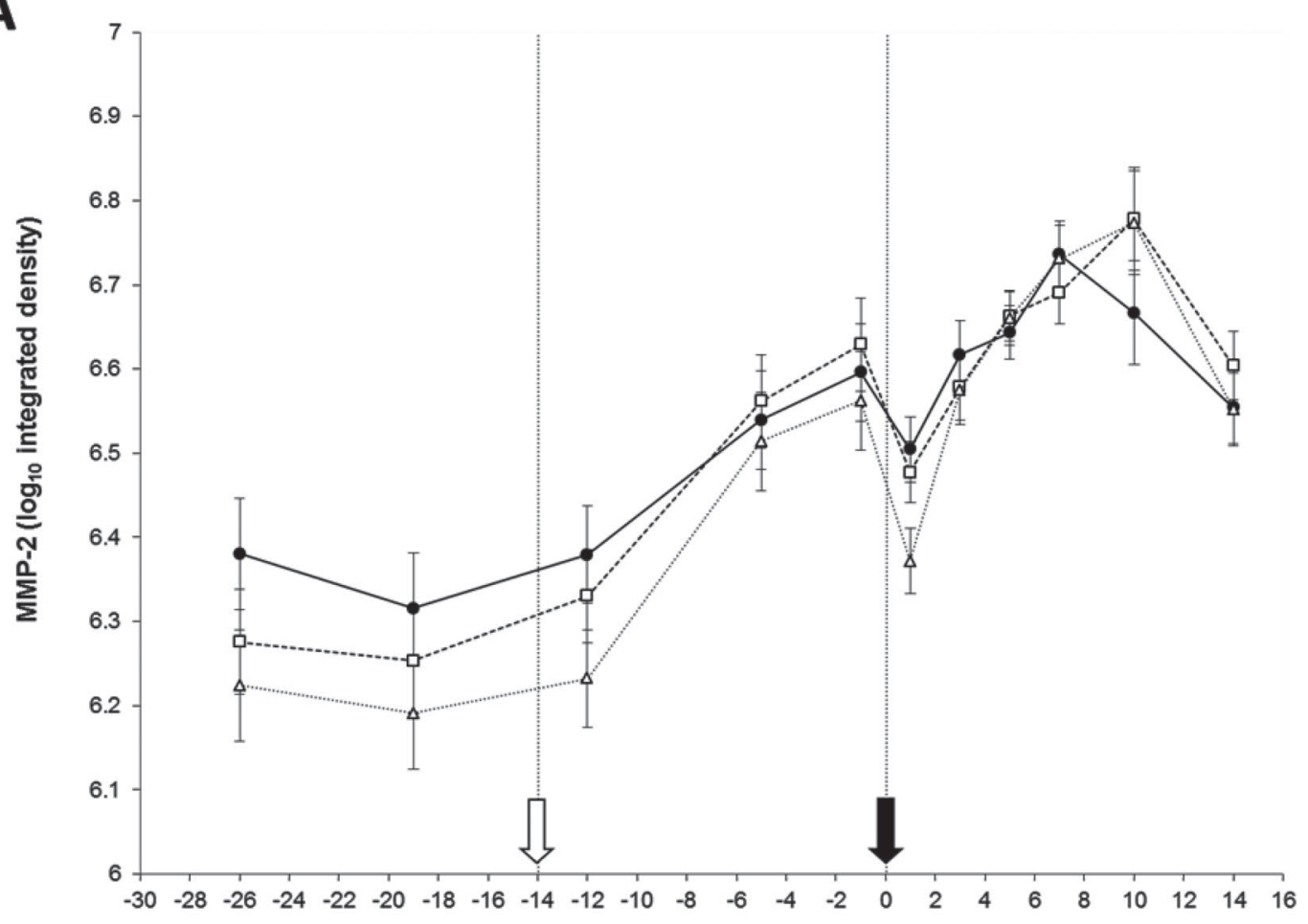

B

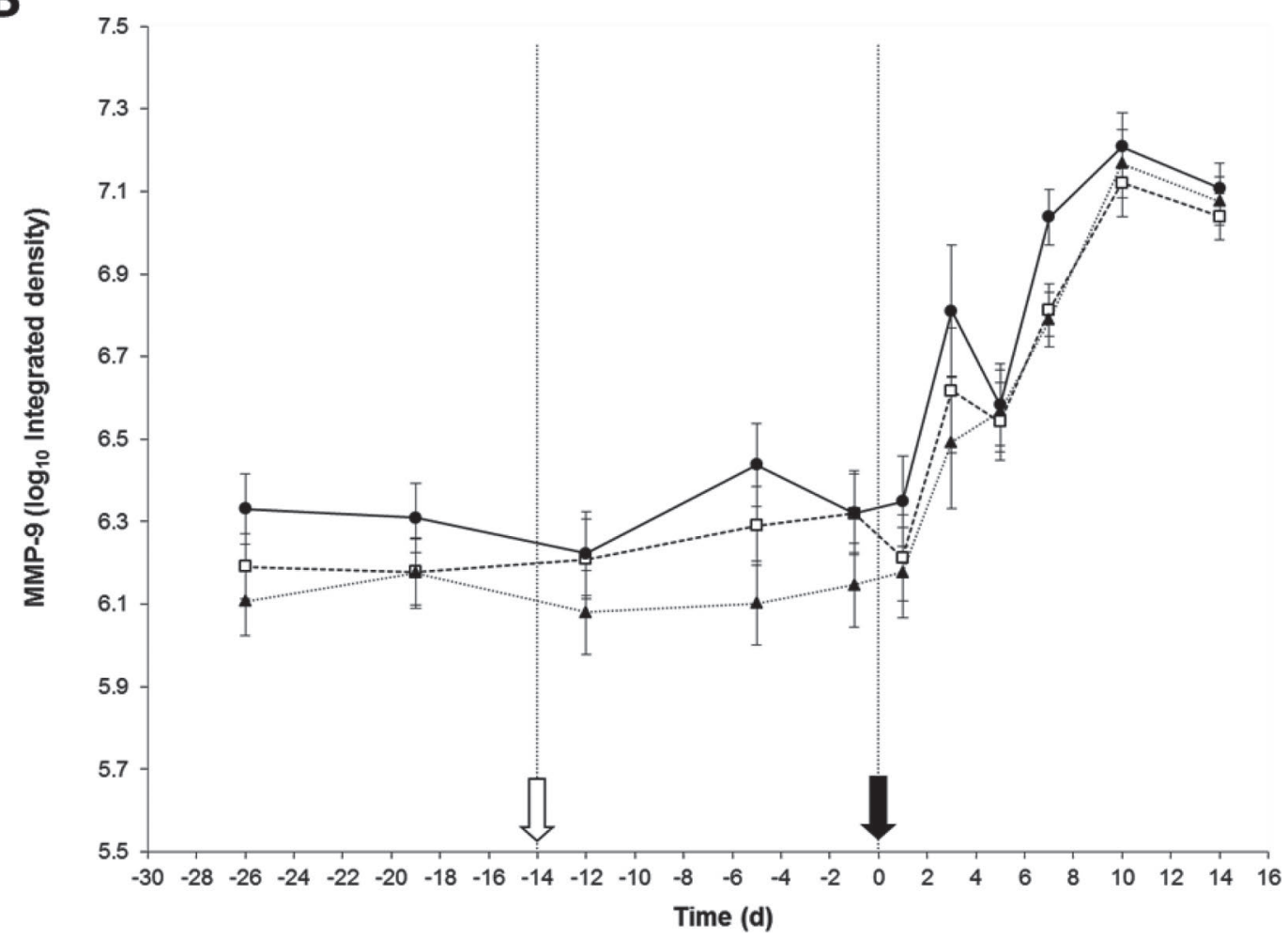

Figure 5. Matrix metalloproteinase-2 (MMP-2; A) and -9 (MMP-9; B) activities in milk and mammary secretions from cows exposed to a short-day photoperiod $(\mathbf{n}=9)$, to a long-day photoperiod $(\square ; \mathrm{n}=10)$, or to a long-day photoperiod and treated with oral administration of melatonin $(\Delta ; \mathrm{n}=9)$ from $14 \mathrm{~d}$ before to $14 \mathrm{~d}$ after drying-off. The white arrow indicates the beginning of the treatments, and the black arrow indicates the start of drying-off. Data are presented as LSM \pm SEM of $\log _{10}$-transformed integrated density values. 
permeability (Nguyen and Neville, 1998; Capuco and Akers, 1999). Consequently, lactose, citrate, and milk fat contents decrease after the cessation of milking, whereas total protein content increases, mainly because of the increases in lactoferrin and blood-originated or mammary-epithelial-cell-originated proteins (or both), such as immunoglobulins and BSA (Nonnecke and Smith, 1984; Hurley, 1989; Shamay et al., 2005). Mammary gland involution also involves recruitment of immune cells (Monks et al., 2002), leading to an increase in SCC (Ollier et al., 2013; Ponchon et al., 2014), as well as tissue restructuring due to the action of several proteases, notably plasminogen activators, plasmin, and MMP (Politis, 1996). These changes in the composition of mammary secretions can be used as indicators of mammary gland involution. In the present study, all the indicators used (BSA, citrate, and lactoferrin concentrations; lactoferrin/citrate ratio; SCC; and MMP-2 and MMP-9 activities) followed the expected changes (Oliver and Sordillo, 1989; Ollier et al., 2014). However, except for MMP-9 activity, the pattern of these changes was not affected by the photoperiod and melatonin treatments. Although citrate concentrations (Figure 4A) in milk and milk secretion did not differ among the treatments, the rapid decrease of citrate concentrations in milk secretion after drying-off may reflect reduction of activities of mammary epithelial cells (Silanikove et al., 2014). The remodeling process that takes place during mammary gland involution involves extracellular matrix degradation through the activation of different proteases, including MMP-2 and MMP-9, and the activities of these enzymes increase during mammary gland involution in cows (Tremblay et al., 2009). Therefore, the trend for a faster increase suggests a positive effect of SDPP on mammary gland remodeling. Nevertheless, none of the results show clearly that involution was affected by the photoperiod or melatonin treatments.

In a recent experiment, Ollier et al. (2014) compared the changes in mammary involution markers in cows in which milk production at drying-off was reduced by prolactin inhibition or feed restriction. Both treatments clearly hastened mammary gland involution, indicating that milk production at drying-off is an important factor modulating mammary gland involution. In the present experiment, although milk production was reduced by SDPP, the magnitude of the decrease was lower than that of the decreases observed by Ollier et al. (2014), and this difference probably explains the lack of effect observed on most indicators of mammary gland involution.

It is well known that photoperiodic manipulation and melatonin feeding have dramatic physiological and production effects in dairy cows (Dahl, 2008; Lacasse et al., 2014). The number of animals used in this study would be sufficient to detect the potential differences for lactoferrin, prolactin, and citrate concentrations among treatments in certain time points of sampling, whereas the treatment effects on other parameters such as SCC and milk production may require more animals per treatment. In addition, separate housing of animals for the SDPP group could have a confounding effect with the treatment. These potential concerns need to be addressed in future studies.

In conclusion, photoperiod modulation and melatonin feeding did not affect the speed of mammary gland involution under the conditions in this study. Exposure to SDPP during late lactation slightly reduced milk production and tended to decrease milking-induced prolactin release, whereas no effects were observed for the LDPP and LDPP+MEL treatments. Mean basal prolactin secretion was lower during the first $2 \mathrm{wk}$ of the dry period when the cows were exposed to SDPP. The effects of SDPP on prolactin secretion and mammary gland involution may need to be reevaluated with a longer exposure before drying-off and more cows.

\section{ACKNOWLEDGMENTS}

The authors thank Martin Beaumont, Kathy Doyon, Marie-Eve Gaillardetz, Dominique Poulin, Guillaume Salaün, and Lisette St-James from the Sherbrooke Research and Development Centre for providing technical assistance, and Paul Meldrum, Carolane Neveu, and the dairy barn staff from McGill University for taking care of the cows. The authors are grateful to Mary Varcoe, from the Translation Bureau (Ottawa, Ontario, Canada), Public Works and Government Services Canada, for her careful editing of this manuscript. The authors also thank the National Hormone and Peptide Program (Torrance, CA) and A. F. Parlow for providing the bovine prolactin and antibodies. This research was financially supported by the Action Concertée Novalait-Fonds de Recherche du Québec, Nature et Technologie-Ministère de l'Agriculture, des Pècheries et de l'Alimentation du Québec, Agriculture et Agroalimentaire Canada.

\section{REFERENCES}

Accorsi, P. A., B. Pacioni, C. Pezzi, M. Forni, D. J. Flint, and E. Seren. 2002. Role of prolactin, growth hormone and insulin-like growth factor 1 in mammary gland involution in the dairy cow. J. Dairy Sci. 85:507-513.

Akers, R. M., W. E. Beal, T. B. McFadden, and A. V. Capuco. 1990. Morphometric analysis of involuting mammary tissue after 21 or 42 days on non-suckling. J. Anim. Sci. 68:3604-3613.

Auchtung, T. L., A. G. Rius, P. E. Kendall, T. B. McFadden, and G. E. Dahl. 2005. Effects of photoperiod during the dry period on prolactin, prolactin receptor, and milk production of dairy cows. J. Dairy Sci. 88:121-127. 
Auldist, M. J., S.-A. Turner, C. D. McMahon, and C. G. Prosser. 2007. Effects of melatonin on the yield and composition of milk from grazing dairy cows in New Zealand. J. Dairy Res. 74:52-57.

Bernier-Dodier, P., C. L. Girard, B. G. Talbot, and P. Lacasse. 2011 Effect of dry period management on mammary gland function and its endocrine regulation in dairy cows. J. Dairy Sci. 94:4922-4936.

Capuco, A. V., and R. M. Akers. 1999. Mammary involution in dairy animals. J. Mammary Gland Biol. Neoplasia 4:137-144.

CCAC. 1993. Guide to the care and use of experimental animals. 2nd ed. Vol. 1. Canadian Council on Animal Care, Ottawa, ON, Canada.

Dahl, G. E. 2008. Effects of short day photoperiod on prolactin signaling in dry cows: A common mechanism among tissues and environments. J. Anim. Sci. 86:10-14.

Dahl, G. E., B. A. Buchanan, and H. A. Tucker. 2000. Photoperiodic effects on dairy cattle: A review. J. Dairy Sci. 83:885-893.

Dahl, G. E., T. H. Elsasser, A. V. Capuco, R. A. Erdman, and R. R. Peters. 1997. Effects of a long daily photoperiod on milk yield and circulating concentrations of insulin-like growth factor-I. J. Dairy Sci. 80:2784-2789.

Dahl, G. E., and D. Petitclerc. 2003. Management of photoperiod in the dairy herd for improved production and health. J. Anim. Sci. 81(Suppl. 3):11-17.

Dingwell, R. T., T. F. Duffield, K. E. Leslie, G. P. Keefe, L. DesCoteaux, D. F. Kelton, K. D. Lissemore, Y. H. Shukken, P. Dick, and R. Bagg. 2002. The efficacy of intramammary tilmicosin at dryingoff, and other risk factors for the prevention of new intramammary infections during the dry period. J. Dairy Sci. 85:3250-3259.

Flint, D. J., M. Boutinaud, C. B. A. Whitelaw, G. J. Allan, and A. F. Kolb. 2006. Prolactin inhibits cell loss and decreases matrix metalloproteinase expression in the involuting mouse mammary gland but fails to prevent cell loss in the mammary glands of mice expressing IGFBP-5 as a mammary transgene. J. Mol. Endocrinol. $36: 435-448$.

Garcia-Hernandez, R., G. Newton, S. Horner, and L. C. Nuti. 2007. Effect of photoperiod on milk yield and quality, and reproduction in dairy goats. Livest. Sci. 110:214-220.

Garcia-Ispierto, I., A. Abdelfatah, and F. López-Gatius. 2013. Melatonin treatment at dry-off improves reproductive performance postpartum in high-producing dairy cows under heat stress conditions. Reprod. Domest. Anim. 48:577-583.

Holst, B. D., W. L. Hurley, and D. R. Nelson. 1987. Involution of the bovine mammary gland: Histological and ultrastructural changes. J. Dairy Sci. 70:935-944.

Hurley, W. L. 1989. Mammary gland function during involution. J. Dairy Sci. 72:1637-1646.

Lacasse, P., V. Lollivier, R. M. Bruckmaier, Y. R. Boisclair, G. F Wagner, and M. Boutinaud. 2011. Effect of the prolactin-release inhibitor quinagolide on lactating dairy cows. J. Dairy Sci. 94:1302-1309

Lacasse, P., V. Lollivier, F. Dessauge, R. M. Bruckmaier, S. Ollier, and M. Boutinaud. 2012. New developments on the galactopoietic role of prolactin in dairy ruminants. Domest. Anim. Endocrinol. 43:154-160.

Lacasse, P., C. M. Vinet, and D. Petitclerc. 2014. Effect of prepartum photoperiod and melatonin feeding on milk production and prolactin concentration in dairy heifers and cows. J. Dairy Sci. 97:3589-3598.

Miller, A. R. E., R. A. Erdman, L. W. Douglass, and G. E. Dahl. 2000. Effects of photoperiodic manipulation during the dry period of dairy cows. J. Dairy Sci. 83:962-967.
Miller, N., L. Delbecchi, D. Petitclerc, G. F. Wagner, B. G. Talbot, and P. Lacasse. 2006. Effect of stage of lactation and parity on mammary gland cell renewal. J. Dairy Sci. 89:4669-4677.

Monks, J., F. J. Geske, L. Lehman, and V. A. Fadok. 2002. Do inflammatory cells participate in mammary gland involution? J. Mammary Gland Biol. Neoplasia 7:163-176.

Morrissey, A. D., A. W. N. Cameron, and A. J. Tilbrook. 2008. Artificial lighting during winter increases milk yield in dairy ewes. J. Dairy Sci. 91:4238-4243.

Nguyen, D.-A. D., and M. C. Neville. 1998. Tight junction regulation in the mammary gland. J. Mammary Gland Biol. Neoplasia $3: 233-246$

Nonnecke, B. J., and K. L. Smith. 1984. Biochemical and antibacterial properties of bovine mammary secretion during mammary involution and at parturition. J. Dairy Sci. 67:2863-2872.

Oliver, S. P., and K. L. Smith. 1982. Nonantibiotic approach in control of bovine mastitis during dry period. J. Dairy Sci. 65:2119-2124.

Oliver, S. P., and L. M. Sordillo. 1989. Approaches to the manipulation of mammary involution. J. Dairy Sci. 72:1647-1664.

Ollier, S. X. Zhao, and P. Lacasse. 2013. Effect of prolactin-release inhibition on milk production and mammary gland involution at drying-off in cows. J. Dairy Sci. 96:335-343.

Ollier, S., X. Zhao, and P. Lacasse. 2014. Effects of feed restriction and prolactin-release inhibition at drying off on metabolism and mammary gland involution in cows. J. Dairy Sci. 97:4942-4954.

Peters, R. R., L. T. Chapin, R. S. Emery, and H. A. Tucker. 1981. Milk yield, feed intake, prolactin, growth hormone, and glucocorticoid response of cows to supplemented light. J. Dairy Sci. 64:1671-1678.

Politis, I. 1996. Plasminogen activator system: Implications for mammary cell growth and involution. J. Dairy Sci. 79:1097-1107.

Ponchon, B., P. Lacasse, N. Silanikove, S. Ollier, and X. Zhao. 2014. Effects of intramammary infusions of casein hydrolysate, ethylene glycol-bis( $\beta$-aminoethyl ether)-N,N,N',N'-tetraacetic acid, and lactose at drying-off on mammary gland involution. J. Dairy Sci 97:779-788

Rajala-Schultz, P. J., J. S. Hogan, and K. L. Smith. 2005. Short communication: Association between milk yield at dry-off and probability of intramammary infections at calving. J. Dairy Sci. 88:577-579.

Sanchez-Barcelo, E. J., M. D. Mediavilla, S. A. Zinn, B. A. Buchanan, L. T. Chapin, and H. A. Tucker. 1991. Melatonin suppression of mammary growth in heifers. Biol. Reprod. 44:875-879.

Shamay, A., R. Homans, Y. Fuerman, I. Levin, H. Barash, N. Silanikove, and S. J. Mabjeesh. 2005. Expression of albumin in nonhepatic tissues and its synthesis by the bovine mammary gland. J. Dairy Sci. 88:569-576.

Silanikove, N., U. Merin, F. Shapiro, and G. Leitner. 2013. Early mammary gland metabolic and immune responses during natural-like and forceful drying-off in high-yielding dairy cows. J. Dairy Sci. 96:6400-6411.

Silanikove, N., U. Merin, F. Shapiro, and G. Leitner. 2014. Milk metabolites as indicators of mammary gland functions and milk quality. J. Dairy Res. 81:358-363.

Travers, M. T., M. C. Barber, E. Tonner, L. Quarrie, C. J. Wilde, and D. J. Flint. 1996. The role of prolactin and growth hormone in the regulation of casein gene expression and mammary cell survival: Relationships to milk synthesis and secretion. Endocrinology 137:1530-1539.

Tremblay, G., P. Bernier-Dodier, L. Delbecchi, G. F. Wagner, B. G. Talbot, and P. Lacasse. 2009. Local control of mammary involution: Is stanniocalcin-1 involved? J. Dairy Sci. 92:1998-2006. 